\title{
DLX1 wt Allele
}

National Cancer Institute

\section{Source}

National Cancer Institute. DLX1 wt Allele. NCI Thesaurus. Code C133661.

Human DLX1 wild-type allele is located in the vicinity of $2 \mathrm{q} 31.1$ and is approximately $5 \mathrm{~kb}$ in length. This allele, which encodes homeobox protein DLX-1, may play a role in brain and facial morphogenesis. 